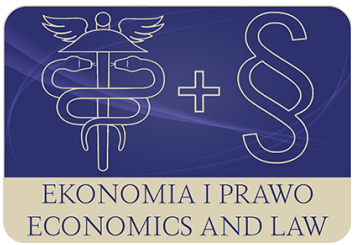

EKONOMIA I PRAWO. ECONOMICS AND LAW

Volume 15, Issue 4, December 2016

p-ISSN 1898-2255, e-ISSN 2392-1625

www.economicsandlaw.pl

ORIGINAL ARTICLE

received 20.10.2015; revised 30.07.2016; accepted 31.12.2016

Citation: Kamińska, K. (2016). Institutional and legal conditions for the German stabilization policy during the economic crisis 2008-2009. Ekonomia i Prawo. Ecomomics and Law, 15(4): 469-480.

doi:10.12775/EiP.2016.031.

\title{
Institutional and legal conditions for the German stabilization policy during the economic crisis 2008-2009
}

\author{
KATARZYNA KAMIŃSKA \\ Kujawy and Pomorze University, Faculty of Law, Administration and Economics, \\ ul. Toruńska 55-57, 85-023 Bydgoszcz, Poland \\ 曰kkam@mat.umk.pl
}

\begin{abstract}
Motivation: The economic crisis of 2008-2009 and its consequences have raised a debate among economists concerning the effectiveness of methods stabilizing economy arising

from the recommendations of economic theories forming the mainstream economy.

Results: The necessity to take anti-crisis measures in the countries affected by it resumed the interest in the recommendations proposed within this realm by John Maynard Keynes. Keynesian solutions have been globally adopted as a basis for anti-crisis stabilization policy. In economic policy it has been manifested primarily as the increased government intervention in economy via the increase of costs and enlarged budget deficits. One of the countries that have applied such a solution was the Federal Republic of Germany.

Aim: The aim of this article is presenting the institutional and legal means of German stabilization policy as well as attempting to evaluate their effectiveness in restoring macroeconomic balance in Germany. In this regard, Keynesian Act to Promote Economic Stability and Growth, passed in 1967, which enabled using the appropriate remedial measures was addressed in detail.
\end{abstract}

Keywords: stabilization policy; keynesianism; Act to Promote Economic Stability and Growth JEL: E3; E6; K00; Pl; O40

\section{Introduction}

An inherent feature of modern economy is the presence of international crises. Their presence stems mainly from the processes of globalization that gave rise 
to considerable opening of national economies and were followed by the evolution of close ties among them. The outcomes of this development have included rapid spreading of various economic tendencies among them, including the recessionary ones. The crisis of 2008-2009 triggered economic declines in many countries around the world. Therefore, a debate has been opened within the economic sciences; the focal point of the discussion has been the effectiveness of methods employed to stabilize the economy arising from the recommendations of economic theories forming the mainstream economy. The need to introduce anti-crisis measures in the countries affected by the said crisis has resumed the interest in the recommendations proposed by John Maynard Keynes, and Keynesian solutions have been adopted as a basis for anti-crisis stabilization policy around the world. In economic policy, has been manifested mainly by increased government intervention in the economy via the expansion of costs and the growth of budget deficits. One of the first euro-zone countries, which have been strongly affected by the crisis is the Federal Republic of Germany. The aim of this article is presenting the institutional and legal means of German stabilization policy and attempting to evaluate their effectiveness in restoring macroeconomic balance in Germany. In this regard, particular attention was paid to Keynesian Act to Promote Economic Stability and Growth passed in 1967 that enabled using the appropriate return remedial measures.

\section{The methodology of research}

The article uses the qualitative analysis method that includes descriptive analysis, case studies, and elements of economic analysis of law.

\section{Act as the foundation stabilization state intervention}

The economic policy implemented in Germany after World War II has been a part of an economic system called social market economy (Soziale Marktwirtschaft). This system has evolved systematically over the years. The 1967 it became an important turning point in the implementation of the scheme and brought significant changes in West German economic policy. The implementation by the Bundestag on 8 June, 1967 the Act to Promote Economic Stability and Growth (Gesetz zur Förderung der Stabilität und des Wachstums der Wirtschaft) allowed for introducing major changes the shape of West German economic model. This document enabled a comprehensive state intervention in the economy, and its purpose was to ensure economic balance and to create favorable conditions for sustainable economic development. The objectives of the so-called magic quadrangle set out in the Act: price stability; high level of employment; balanced foreign trade, and steady and sustainable economic growth, officially became the objectives of West Germany's economic policy. Since it entered into force, the Act had a fundamental influence on the direction 
German economy was heading, especially in periods of recession and when it faced the first signs of weakening of economic growth ${ }^{1}$.

The Act to Promote Economic Stability and Growth (Gesetz zur Förderung der Stabilität und des Wachstums der Wirtschaft, StWG) and the change of paragraph 2, Article 109 of German constitution ${ }^{2}$ connected with it, became the legal basis for the implementation of the principles of Keynesian economic policy. The introduction of these changes resulted in the emergence of a new kind of economic policy - the stabilization policy. The government pledged to submit an annual report on the state of the economy. This report, called Jahreswirtchaftsbericht, is still published by the Ministry of Economy at the beginning of each year. It contains a list of targets that the government has committed itself to complete in economic policy in a given year, the measures for their implementation and the response to the opinions issued by the German Council of Economic Experts $^{3}$. Additionally, every two years the government prepares, Subventionsbericht, a report on the subsidization of economic activities (Pätzold \& Baade, 2008, p. 3 and further).

The implementation of the Act, then, led to the centralization of economic policy and weakening the principle of subsidiarity, i.e. the roles and responsibilities resulting from various levels of policy have been surrendered to the state and some of its institutions.

Section 1 of the Act reads: 'In their economic and fiscal policy measures, the Federation and the Länder shall observe the requirements of the overall economic equilibrium. These measures shall be taken in such a way that, within the framework of the market economy, they simultaneously contribute to the price stability, to a high level of employment and the external equilibrium, accompanied by steady and adequate economic growth' (Act of 8 June, 1967).

The Act requires the federal state and particular Länder to adjust their respective budgets to meet the needs of general economic equilibrium defined by the magic quadrangle. It defines the measures to be implemented in the event of economic imbalances, as a result of a downturn or/and economic overheating. A high priority is given to the employment of budgetary resources to regulate the demand and the supply in the respective phases of the business cycle. The project was a counter-cyclical policy plan established on state resources. The accumulation of funds for the appropriate objectives, as a part of the medium-term planning of public finances, was to lead to the elimination of a number of irregularities in the structure of expenditure from the federal budget, especially in terms of the expenses on science research and education; infrastructure; energy management; agriculture, and regional economic structure

\footnotetext{
${ }^{1}$ A more extensive analysis is included in Kamińska (2014).

2 German books on the subject use the term 'post-Keynesian policy' (Pätzold \& Baade, 2008).

3 Its task was to analyze the current economic situation and anticipate its future development as well as to assist the state authorities responsible for economic policy in making decisions.
} 
(Polszakiewicz, 1976, p. 23). The federal law took upon itself the obligation to undertake the counter-cyclical measures in the design and the implementation of the budget (Section 5 and 6 of the Act). To accomplish this goal, three sets of measures were established (Thiemie, 1995, pp. 107-109):

a. the monetary policy measures - to allow the government affect the capital market, extending abilities of the Federal Bank in combating disparities in the development and growth of inflation via intervening in the foreign exchange market (Section 29 and Section 30 of the Act);

b. the fiscal policy measures:

- paragraph 1 of Section 9 requires the adjustment the scope and the structure of expenditure under the medium-term financial planning (five-year) to the business cycle expectations. Changes in expenses become possible due to shortening, postponing or accelerating the state investment plans, prepared under the long-term investment programs ( Section 10);

- Section 26 and Section 27 recognize that changes in revenues necessary for economic and political reasons can be introduced by raising or lowering the tax rates on personal income as well as a corporate tax by approximately $10 \%$. They can apply for no longer than 12 months. Additional revenues that arise as a result of the increase in the tax rate, conformant to the Act, will not be returned to economic operators. The federal state may also differentiate the terms of deductions, depending on the economic needs to affect the investment activities of the enterprises;

- under Section 7 and Section 15 of the Act, the surplus created as the result of the reduction of the expenses or the increase of the revenues is to be deposited at the Bundesbank as equalization economic reserves. These measures may be used to cover budget deficits that arise during phases of the economic downturn. This instrument is designed to eliminate budget surpluses and cover budget deficits with extra money;

- Section 19 provides the possibility of introducing limits on borrowing loans by local institutions if it becomes necessary due to general economic climate;

- means of 'moral persuasion' - in the form of institutionalized moral impact on those social groups that can either facilitate or hinder the introduction of certain counter-cyclical events. Two institutions were created for this purpose; the first was the Economic Policy Council (Konjunkturrat der öffentlichen Hand). Its task was to coordinate decisions made by economic operators, to act as an advisory and evaluative body in terms of meeting the demand of public finance for credit (Schmoeckel \& Kaiser, 2005, p. 309). The members of the Council included the Minister of Economy and Finance, the representatives of the Länder, and the communities. It was to examine and determine counter-cyclical measures unique to a given situation. The second institution was so-called coordinated action, or 'concentrated action' (Konzentrierte Aktion) that was introduced whenever the risk of failure of one of the new economic policy objectives appeared. The primary function of this institution was an attempt to build a platform for communica- 
tion between the unions and the employers. It included the representatives of the federal government, the trade unions, the employers and the Deutsche Bundesbank. The literature on the subject referred to this institution as the starting point for forming the pay rates on the basis of negotiations on matters of collective agreements ${ }^{4}$. Apart from the institutions that supported new economic policy, the Stabilization Act gave a legal foundation for the creation of an additional tool economic policy - Downturn Stabilization Fund, otherwise known as Cyclical Reserve Fund. Its functioning relied on the fact that in a situation of economic overheating, when production capacity failed to keep pace with rapidly growing economic demand, thus introducing the threat of inflation, the federal government made payments to it, thus reducing budget expenditure. In the event of an economic downturn, the government might decide to disburse the funds from the account to increase global demand.

\section{Stabilization policy in Germany during the crisis of years 2008-2009}

The Economic history of Germany has noted two cases of employing special programs to stimulate economic situation (the recession of 1967-1968 and the crisis of 2008-2009). This fact proves that the StWG recommendations for the actions of the government in the event of changes in the size of global demand have been treated seriously and consistently. Nevertheless, even before the outbreak of the 2008-2009 crisis, in 2006 the amended version of StWG was introduced in Germany. The first paragraph of Section 13 of the Act extended general economic obligation to maintain general economic balance at ERP-Sondervermö$g e n^{5}$. In practice, it allowed for including those funds into Downturn Stabilization Fund and using them in situations threatening general economic balance. Deutsche Bundesbahn was subordinated to the Federal Ministry of Transport and Digital Infrastructure and the Ministry of Finance to comply with the provisions of Section 1 of StWG (Section 13, paragraph 2). Public bodies, institutions, foundations created and controlled directly by federal law were to take into account the recommendations of this paragraph (Section 13, paragraph 3$)^{6}$.

${ }^{4}$ It was expected that thanks to those consultations the process of social integration of the aims put forward in the magic quadrangle. This concentrated action was ended in the 1970s, due to extensive disagreement on the cession rule.

5 European Recovery Program, ERP-Sondervermögen, commonly known as the Marshall Plan.

${ }^{6}$ As a part of its actions, the government adopted the stabilization package. The most important element of the introduced changes was a law extending the abilities of stabilization the financial markets passed April 7, 2009, Finanzmarktstabilisierungsergänzungsgesetz, FMStErgG. Additionally, the stabilization fund (Sonderfonds Finanzmarktstabilisierung SoFFin) and the institution of Bundesanstalt für Finanzmarktstabilisierung (FMS) were established. As part of the stabilization pack-age the bankruptcy laws and the settlement 
Strong ties of German economy with foreign markets, in particular its dependence on imports of capital from the US, and the dependence of German business cycle on the state of global economy meant that the consequences of global financial crisis affected German economy as well. In the fourth quarter of 2008, a noticeable decline in exports of German goods became apparent, which included the export of automobiles, machinery, industrial equipment, and chemical products. In comparison to the previous year, the export was reduced by $6.2 \%$. The GPD factor collapsed dramatically (chart 1 ).

This decline was particularly strong in export-oriented sectors while sectors associated with private consumption remained less affected by the crisis. The emerging recession accompanied by a significant reduction in the growth rate of the investment in devices. At the turn of 2007 and 2008 the investment rate decreased from $6.9 \%$ to $5.3 \%$. It was predicted that the following year it could fall to $-11.9 \%$ (Bundesministerium für Wirtschaft und Technologie, 2009, p. 70). As a result of the collapse of exports in 2009 (-16.3\%), capital expenditures decreased by $-22.9 \%$ (Bundesministerium für Wirtschaft und Technologie, 2011, p. 7). This downward trend could also be observed in the import of goods and services. The decline in those ratios resulted in a decrease in GDP by $5.1 \%$ in 2009, and consequently, an increase in the unemployment, a drop in domestic demand and private consumption as well as higher prices.

On 5 November 2008 German government accepted a diverse program called the Economic Stimulus Package I (Konjunkturpaket I) covering activities that were to stimulate global economic growth. It included a special platform for companies and a family-support program (Familienleistungsgesetz) (Gesetz zur Förderung von Dienstleistungen haushaltsnahen Familien, 2008). Among its benefits were the support for the investments in transport, the initiatives to stimulate demand in businesses, households, and local governments: personal income tax deductions, increase in family benefits, reduction in the insurance premiums for the unemployed or a credit program for institutions Kreditanstalt für Wiederaufbau - Reconstruction Credit Institute for medium-sized enterprises under the name Beschäftigungssicherung durch Wachstumsstärkung (Occupation protection by strengthening growth) ${ }^{7}$. The volume of the package regulations in order to save medium companies from insolvency were introduced. Since the introduction of the changes, the balance sheet over-indebtedness will not be sufficient for the implementation of the bankruptcy proceedings. In order to obtain more efficient monitoring of the management of the public finances, both at the federal level as well as in individual Landen, as of 1 January 2010, under Stabilitätsratgesetz (StabiRatG, $\$ 1$ ), the Stabilization Council was established. Formally, this institution was the successor to the Financial Planning Council, which ceased to exist on June 2, 2010 (Kamińska, 2014, p. 395 and further).

7 The referred monograph by W. Małachowski (2013), includes a division into three economic packages: Kojunkturpaket 0, Konjunkturpaket I and Konjunkturpaket II. The author states that Konjunkturpaket 0 was passed by the federal government on October 14, 2008 and was called 'The package of actions to reduce the tax burden, the stabilization of the costs of social security, and the investment in family'. It was financed from the federal budget, 
was 31.11 bln EUR, which constituted 1.5\% of GDP. Most funds were assigned to the reduction of the unemployment insurance contributions and the possibility of deducting from the income tax, since 2010, health and care insurances of the taxpayers, their spouses, and their offspring as well as the introduction for the period of 2009-2010 the declining balance depreciation. German academic circles criticized the liberal concept of economic policy and its distortions. It was pointed out that the cause of the crisis was the malfunctions in the operating and the supervision of the US banking system combined with widespread speculation in the provision of housing loans and the flow of investment funds and mortgages (Kotz et al., 2008, pp. 291-301). In early spring 2009, one of the leading Berlin research institutes, DIW, issued an opinion in which it was stated that the economic slowdown was only partly the result of the US financial crisis. Due to strong production and financial ties between the US and the world markets (including German market), the international risks that might have arisen from that situation were ignored ${ }^{8}$. The proposals to increase the role of the state by increasing its scope of oversight and the range of its intervention appeared.

In their appraisal for the period 2009-2010, German Council of Economic Experts recommended the extension of the employed instruments of stabilization policy by discretionary fiscal policy measures (Sachverständigenrat, 2009, p. 249). It was emphasized that the need to use fiscal policy measures is the result of the unique nature of the crisis. In the situation of a regular business cycle and small shocks, applying active economic policy is not justified. Monetary policy measures and the operation of automatic economic stabilizers were still considered typical means of stabilization policy (Sachverständigenrat, 2009, p. 166). This postulate was a clear turn toward the new Keynesian policy. The previous appraisal presented a cautious stance on the use of this type of measure but contained specific recommendations for conducting this kind of policy, taking into account the conditions of the growth policy. The Council was interested in the short-term stabilization of the business cycle and the stimulation of the medium- and the long-term growth (Sachverständigenrat, 2008, p. 247 and further). A similar opinion on the increasing state of intervention in the economy by means of counter-cyclical policy measures was included in the biyearly Gemeintschatfsdiagnose for the national economy, released in the fall of 2008, which stressed the need to start the economic cycle packages (Projektgruppe Gemeinschaftsdiagnose, 2009, p. 67).

The anti-crisis strategy employed by the federal government included goals and the guidelines for the implementation of a number of legislative measures as well as socio-economic decisions. Among the medium-term socio-economic objectives one can distinguish the stimulation of domestic demand, preventing the growth of the unemployment, actions to maintain the level of production,

and its volume was 28.4 bln EUR (Małachowski, 2013, p. 203). In this text, the division adopted by BMF (Bundesministerium der Finanzen) is employed.

${ }^{8}$ This opinion is quoted by Cziomer (2010, pp. 51-52). 
to improve the business environment, and to strengthen the position of enterprises in the field of export (Projektgruppe Gemeinschaftsdiagnose, 2009, p. 56 as cited in Köhrsen, 2011, p. 60).

On February 13, 2009, the Economic Stimulus Package II (Konjunkturpaket II) was passed; it was called Sicherung Stabilität von und Beschäftigung in Deutschland (Securitization of Employment and Stability in Germany). This package has been considered to be the largest economic stimulation program in the history of Germany so far. It included public investment in transport and infrastructure, credit assistance for the businesses, investments in real estate and stocks that would stimulate the consumption'. It included the changes in the income tax, the increase in the investment expenditures and was aimed at helping the automotive industry, which suffered particularly hard during the crisis.

The largest proportion of the expenses in the Economic Stimulus Package II included spending on the improvement of the municipal infrastructure, transportation, funding for kindergartens, schools, or hospitals as well as tax reductions and raising the sums of money that were tax-free. Reducing taxes and social charges were supported by increased money transfers. The resources used constituted discretionary policy tools designed to support the consumption and the investment. The sum of expenses incurred as a result of running this program amounted to 49.89 bln EUR, which was $1.9 \%$ of GDP. Both programs amounted a total budget of 81 bln EUR and were the largest programs of this kind in the countries belonging to the eurozone. Chancellor Angela Merkel described it as her government most difficult decision of the internal policy, which entailed new and significant debt in the current year and the following years (Die Bundesregierung, 2009). The fiscal effects caused by these measures have been assessed as low (Leifels et al., 2009, p. 10)

The implementation of these economic programs entailed various economic and financial consequences. The financial policy became expansionary. The years 2009 and 2010 witnessed a significant increase in the state outgoings (48.1\% of GDP in 2010) and the reduction of the tax burden that was to stimulate the domestic demand (Projektgruppe Gemeinschaftsdiagnose, 2011). A large part of the instruments employed in the packages was related to the promotion of the investment activities in the economy, based mainly on using preferential loans and government investment institutions managed by KfW, Kreditanstalt für Wiederaufbau, Reconstruction Credit Institute ${ }^{10}$. The consequence of this direction of the fiscal policy was a burden on public finances in 2009-2010 to a total amount of 82.3 bln EUR, approximately 35.8 bln EUR in 2009, and 46.6 bln EUR in 2010 (Małachowski, 2013, p. 9). The situation contributed to an increase of the national debt. Its share in GDP in 2009-2011 increased from $74.5 \%$ to $80.5 \%$. In terms of the budget balance, by 2010 one can see an increase in the budget deficit - 4.3\% of GDP (Projektgruppe Gemeinschaftsdiagnose, $2010 ; 2011)$. As a result of the consolidation efforts, in 2011 it was significantly

\footnotetext{
9 This opinion can be read in Leifels et al. (2009, p. 1).

${ }^{10}$ A more extensive analysis of the subject in Małachowski (2013, p. 207 and further).
} 
reduced. Further, additional expenses related to the protection of jobs by providing loan guarantees to companies and investors were incurred. One of the illustrations of this protective measures could be GM-Opel plant (Frankfurter Allgemeine Zeitung, 2009; Der Spiegel, 2009) ${ }^{11}$.

At the end of May 2009, Article 109 of German constitution was passed; paragraph 3 of the Article allowed for the introduction the counter-cyclical budget by the state. It was about the ability to run a structural deficit beyond $0.35 \%$ of GDP, in the event of an economic recession. In a normal cyclical position, the loans that were taken could not exceed $0.35 \%$ of GDP. The intention of the legislator was to have a pivotal role in the consolidation process of German public finances. This rule will be in force on the federal level since 2016, and in the Länder, since 2020. Until then, the government should balance the budget and reduce the deficit. In the event of natural disasters and emergency situations, which are beyond the state control and seriously affect the financial conditions of the country, it was established that the upper limit of the national debt could be increased by the resolution of the majority of the members of the Bundestag (Grundgesetz für die Bundesrepublik Deutschland, 1949).

\section{Conclusion}

Removing the effects of 2008-2009 crisis within OECD countries created general interest in Keynesian counter-cyclical stabilization policy. One of the countries that have been heavily affected by the crisis is the Federal Republic of Germany. Since 2008, during Angela Merkel's government, a turn towards Keynesian policy has become apparent in German economic policy, mainly due to economic packages. They have been applied in response to a sudden collapse of exports, which resulted in a decrease in the growth rate of investment in equipment and caused a decline in GDP. Certainly, the German economy has shown that it can cope in the face of crisis, and the German government has taken effective measures to protect the economy and the competitiveness of German companies. The legal measures and the institutions of German stabilization policy have been of vital importance. The actions of the German government remained not only of great economic but also psychological importance. They enabled at least partial restoring confidence in the market that had been lost as a result of the crisis, and necessary for its proper functioning. Despite a number of indisputable advantages resulting from the application of cyclical programs in Germany, the question remains, what will be the real costs of conjunctural policy of 2008-2009. Keynes's notion can be successfully treated as a remedy for the economic crisis. The consequence of its application,

${ }^{11}$ As a result of the crisis, General Motors in the USA, the production at GM's Opel plants in Germany and in other European countries was halted. In Germany, the bankruptcy of this company, having many partners and an extensive network of suppliers, would entail the loss of more than 100000 jobs. Therefore, the Merkel government decided to take measures to prevent it (Małachowski, 2013, p. 201). 
however, is an increase in the national debt, as shown by macroeconomic data in Germany. The growing national debt, in turn, is likely to weaken in the future development possibilities of this economy.

\section{References}

Act to Promote Economic Stability and Growth of 8 June 1967 (Federal Law Gazette I, p. 582).

Bundesministerium für Wirtschaft und Technologie. (2009). Jahreswirtschaftsbericht 2009 der Bundesregierung Konjunkturgerechte Wachstumspolitik. Retrieved 04.12.2014 from https://www.bmwi.de.

Bundesministerium für Wirtschaft und Technologie. (2011). Jahreswirtschaftsbericht 2011 der Bundesregierung Deustchland im Aufschwung - den Wohlstand von morgen sichern. Retrieved 04.12.2014 from https://www.bmwi.de.

Bundesministerium für Wirtschaft und Technologie. (2013). Jahreswirtschaftsbericht 2013. Retrieved 04.12.2014 from http://www.bmwi.de.

Cziomer, E. (2010). Wyzwania światowego kryzysu finansowo-gospodarczego dla polityki Niemiec. In M. Lasoń (Ed.). Między kryzysem a wspótpraca gospodarczą. Kaków: Oficyna Wydawnicza AFM.

Der Spiegel. (2009). Vom Staats wegen. Retrieved 04.12.2014 from http:// www.spiegel.de.

Die Bundesregierung. (2009). Regierungserklärung der deutschen Bundesregierung vom 14.01.2009. Retrieved 04.12.2014 from http://bundesregierung.de.

Frankfurter Allgemeine Zeitung. (2009). Nicht nur Opel braucht Hilfe — mehr als 1100 Firmen wollen Staatsgeld. Retrieved 04.12.2014 from http://www.faz. net.

Gesetz zur Förderung von Dienstleistungen haushaltsnahen Familien vom 22.12.2008 (Bundesgesetzblatt Jahrgang 2008 Teil I Nr. 64)

Grundgesetz für die Bundesrepublik Deutschland vom 23 Mai 1949 (Bundesgesetzblatt 1949 Teil I Nr. 1)

Kamińska, K. (2014). Ordoliberalizm i keynesizm - dwie sprzeczne koncepcje w polityce gospodarczej powojennych Niemiec. Unpublished doctoral dissertation, Nicolaus Copernicus University, Torun.

Köhrsen, J.O., (2011). Paradigmenwechsel in der wirtschaftswissenschaftlichen Politikberatung? Der Wandel wirtschftspolitischer Diskurse in Deutschland zwischen 1990 und 2009. IfM Study, 2.

Kotz, H.H., Menkhoff, L., \& Kempa B. (2008). Die internationale Finanzkrise und ihre Folgen. Wirstchaftsdienst, 88(5). doi:10.1007/s10273-008-0795-5.

Leifels, A., Moog, S., Raffelhüschen, B. (2009). Auswirkungen der Konjunkturpakete auf die öffentlichen Haushalte in 2009 und 2012. Freiburg: Albert-Ludwigs-Universität.

Małachowski, W. (2013). Kapitalizm wspótczesnych Niemiec. Warszawa: CeDeWu. 
Pätzold, J., \& Baade D. (2008). Stabilisierungspolitik. Grundlage der nachfrage- und angebotsorientierten Wirtschaftspolitik. München: Vahlen. doi:10.15358/9783800643233.

Polszakiewicz, B. (1976). Długofalowa i antycykliczna polityka interwencyjna państwa w gospodarce Republiki Federalnej Niemiec po II wojnie światowej. Acta Universitatis Nicolai Copernici. Nauki Humanistyczno-Spoteczne. Nauki Polityczne, 8(78).

Polszakiewicz, B. (2005). Periodyzacja współczesnego cyklu koniunkturalnego jako przesłanka efektywnej polityki stabilizacji. In B. Polszakiewicz, \& J. Boehlke (Ed.). Ead instytucjonalny $w$ gospodarce. Torun: UMK.

Projektgruppe Gemeinschaftsdiagnose. (2009). Zögerliche Belebung — steigende Staatsschulden: Gemeinschaftsdiagnose Herbst 2009. Wirtschaft im Wandel, 15(2).

Projektgruppe Gemeinschaftsdiagnose. (2010). Herbst 2010. Retrieved 04.12.2014 from http://www.cesifo-group.de.

Projektgruppe Gemeinschaftsdiagnose. (2011). Herbst 2011. Retrieved 04.12.2014 from http://www.cesifo-group.de.

Sachverständigenrat. (2008). Die Finanzkrise meistern - Wachstumskräfte stärken. Jahresgutachten 2008-09. Retrieved 04.12.2014 from https://www. sachverstaendigenrat-wirtschaft.de.

Sachverständigenrat. (2009). Die Zukunft nicht aufs Spiel setzen. Jahresgutachten 2009-10. Retrieved 04.12.2014 from https://www.sachverstaendigenrat-wirtschaft.de.

Schmoeckel, R., \& Kaiser B. (2005). Die vergessene Regierung. Die große Koalition 1966-1969 und ihre langfristigen Wirkungen. Bonn: Bouvier Verlag.

Thiemie, M.J. (1995). Spoteczna gospodarka rynkowa. Warszawa: C.H. Beck.

\section{Acknowledgements}

Author contributions: author have given approval to the final version of the article. 


\section{Appendix}

Chart 1.

GDP growth, exports of goods and investment in facilities in Germany in 2005-2012 (in \%)

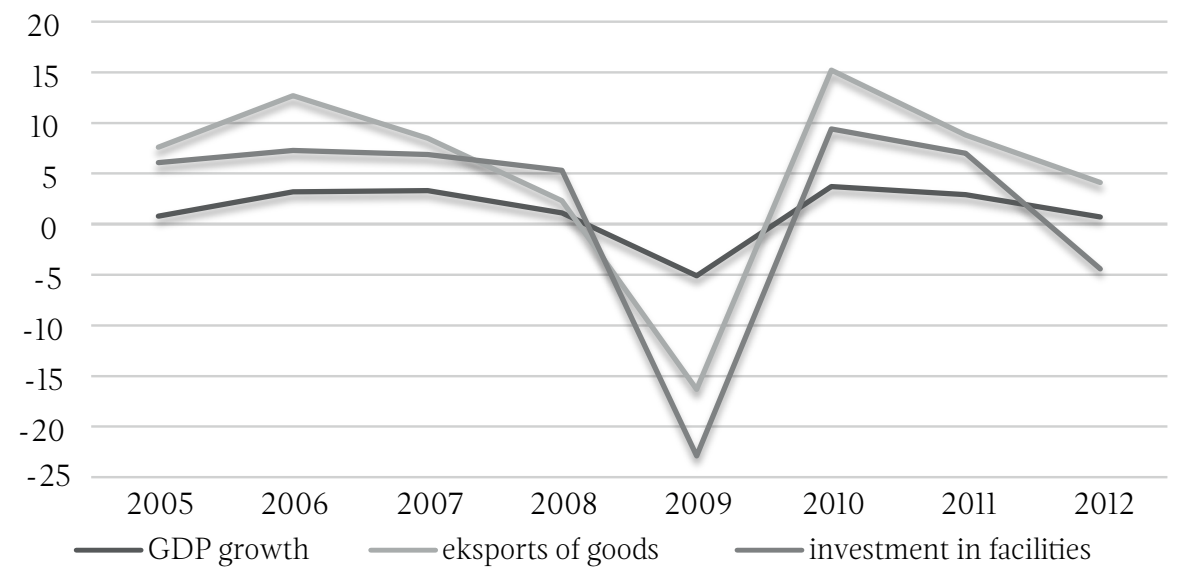

Source: Projektgruppe Gemeinschaftsdiagnose $(2010 ; 2011)$ and Bundesministerium für Wirtschaft und Technologie (2013). 